\title{
Quality changes of fresh-cut lettuce with different oxygen permeability of films during storage
}

\author{
Tae-Young Hwang ${ }^{1}$ (D) \\ 포장 필름의 산소투과율에 따른 신선편의 양상추의 저장 중 품질변화
}

황태영1

Received: 5 November 2017 / Accepted: 9 December 2017 / Published Online: 31 March 2018

(C) The Korean Society for Applied Biological Chemistry 2018

\begin{abstract}
This study investigated the effect of different $\mathrm{O}_{2}$ transmission rate (OTR) of films on surface temperature, weight loss, $\mathrm{pH}, \mathrm{O}_{2}, \mathrm{CO}_{2}$ and sensory characteristics, microbial quality, total phenolic contents and 1,1-diphenyl-2-picryl hydrazyl radical scavenging activity of fresh-cut lettuce during storage at $10{ }^{\circ} \mathrm{C}$ for 7 days. $80 \pm 5 \mathrm{~g}$ of fresh-cut lettuce were packaged with oriented polypropylene films respectively. The OTR of packaging materials was $5,000,8,000$ and $10,000 \mathrm{cc} / \mathrm{m}^{2} \cdot$ day $\cdot \mathrm{atm}$. Quality characteristics showed significant differences during storage. The surface temperature was averaged 13 and lower in higher OTR of films. The weight loss of lettuce ranged from 2.8 to $5.4 \%$ and the highest loss showed in $5,000 \mathrm{cc} / \mathrm{m}^{2} \cdot$ day $\cdot$ atm of film. $\mathrm{pH}$ was increased during storage and the highest $\mathrm{pH}$ was found in 5,000 $\mathrm{cc} / \mathrm{m}^{2} \cdot$ day $\cdot \mathrm{atm}$. The $\mathrm{O}_{2}$ content in the packaging was decreased with increasing $\mathrm{CO}_{2}$ content during storage. The lowest $\mathrm{CO}_{2}$ was found in $10,000 \mathrm{cc} / \mathrm{m}^{2} \cdot$ day $\cdot \mathrm{atm}$. As OTR was decreased, antioxidant profile of lettuce was decreased. Total aerobic bacteria showed from 5.48 to $6.59 \mathrm{log} \mathrm{CFU} / \mathrm{g}$. From the result of the overall sensory test, the marketability of fresh-cut lettuce stored at $10{ }^{\circ} \mathrm{C}$ seemed to be maintained effectively over 5 days.
\end{abstract}

Tae-Young Hwang $(\bowtie)$

E-mail: hty301@jwu.ac.kr

${ }^{1}$ Department of Food Science \& Technology, Jungwon University, Goesangun 367-805, Republic of Korea

This is an Open Access article distributed under the terms of the Creative Commons Attribution Non-Commercial License (http://creativecommons. org/licenses/by-nc/3.0/) which permits unrestricted non-commercial use, distribution, and reproduction in any medium, provided the original work is properly cited.
Keywords Fresh-cut $\cdot$ Lettuce $\cdot$ Modified atmosphere packaging Oriented polypropylene film $\cdot \mathrm{O}_{2}$ transmission rate

\section{서 론}

국화과에 속하는 양상추는 flavonoid류 등 각종 기능성분의 급 원으로, 신선, 편리 및 건강 관련 소비자의 관심 증대와 함께 샐러드로 가장 많이 이용되고 있는 채소이다(Chun 등, 2005; Llorach 등, 2008). 신선 과일 및 채소의 소비 편리성을 강조한 샐러드로 제조하기 위해서는 fresh-cut, minimal processing 등으 로 불리는 신선편의 가공을 적용하는데, 절단, 세척 및 포장 후 냉장유통을 하는 것이 일반적이다(Barmore 1987; Ahvenainen 1996; Rico 등, 2007). 신선편의 가공에 따른 신선편의 식품의 품질변화 및 위생 안전성에 대한 국내외 연구가 활발히 보고되 고 있으며, 국내에서도 2007년부터 이러한 신선편의 식품 관련 규격을 신설하여 관리하고 있다(Hwang과 Moon 2005; KFDA 2007).

신선편의 식품의 저장 품질을 향상시키기 위해 다양한 기술을 적용하고 있는데 기체조절포장(modified atmosphere packaging, $\mathrm{MAP}$ )이 그 일례이다(Fonseca 등, 2002). 신선편의 식품의 포장을 위해 주로 사용되는 필름은 polypropylene (PP) 및 polyethylene 재질이며, 이중 $\mathrm{PP}$ 재질을 연신 처리하여 차단성이 뛰어난 oriented polypropylene (OPP) 필름에 방담기능(anti-fog)을 부가 한 필름이 널리 사용되고 있다(Hwang 2013). 관련하여 신선편 의 식품의 포장 내 기체조성의 변화를 적용하는 연구(Barnmore 1987; Zagory와 Kader 1988; Sandhya 2010), 항균성 필름을 활용한 능동적 포장의 적용(Labuza와 Brene 1989), 온도와 산 소분압에 따른 양상추의 품질변화(Smyth 등, 1988) 및 로메인 
양상추의 포장 내 초기 산소 함량 및 필름의 산소투과율에 따 른 품질변화 연구 $(\mathrm{Kim}$ 등, 2005)가 보고되고 있다. 한편 신선 편의 과일 및 채소에 대한 다양한 포장 환경 하에서의 품질연 구가 활발한데 반해, 국내의 유통환경 등을 고려한 산소투과율 등 실제 산업체에서 바로 적용할 수 있는 세분화되고 실용적인 연구가 추가로 요구되고 있다.

따라서 본 연구에서는 서로 다른 산소투과율을 가지는 OPP 재질을 리드 필름으로 하여 용기 포장한 신선편의 양상추의 저 장 시 품질 변화를 조사하고 신선편의 식품의 제품설계 및 유 통 중 품질 관리를 위한 기초 자료로 활용하고자 하였다.

\section{재료 및 방법}

\section{양상추의 신선편의 가공 및 투과율 별 필름 포장}

실험재료인 양상추는 구입 즉시 보냉하여 이동하였고, 구입 당 일 실험에 사용하였다. 이물 제거, 다듬기 후 샐러드 사이즈(가 로, 세로 각 $4 \mathrm{~cm}$ )로 절단하고, 수도수에 3 분간 침지, 세척하였 다. 종이타올을 이용하여 물기를 제거한 양상추는 각 $80 \pm 5 \mathrm{~g}$ 씩 $\mathrm{OPP}$ 용기에 담고, $\mathrm{OPP}$ 필름(두께 $80 \mu \mathrm{m}$ )으로 밀봉포장(model TPS-MA1, MAP Co., Gyenggido, Korea)하여 10로 설정한 인 큐베이터(Model VS-8480, Vision scientific Co, Ltd., Gyenggido, Korea)에 저장하면서 품질변화를 조사하였다. OPP 필름의 산소 투과율은 각각 $5,000,8,000,10,000 \mathrm{cc} / \mathrm{m}^{2} \cdot \mathrm{day} \cdot \mathrm{atm}$ 이었으며, 이 는 $3,000-15,000 \mathrm{cc} / \mathrm{m}^{2} \cdot \mathrm{day} \cdot \mathrm{atm}$ 의 투과율 중 예비실험을 통해 선정하였다. 초기 포장 용기 내 기체 조성은 산소 $21.0 \pm 0.3 \%$, 이산화탄소 $0.3 \pm 0.0 \%$ 이었다.

\section{표면온도 및 중량 변화 측정}

저장 중 신선편의 양상추의 표면온도는 비접촉식 적외선 온도 계(DT8380-951, Tianjin Cheerman Technology Co., Ltd., Tianjin, China)를 사용하여 리드필름의 중심부위를 측정하였고, 저장 중 중량 변화는 초기 중량에 대한 측정 시의 감량비율을 계산하여 중량감소율 $(\%)$ 로 나타내었다.

\section{$\mathrm{pH}$, 갈변도 변화}

신선편의 가공한 양상추의 저장 중 $\mathrm{pH}$ 변화는 시료와 증류수 를 1:1로 혼합하여 균질화한 다음 여과하여 $\mathrm{pH}$ meter $(420 \mathrm{~A}$, Orion, Beverly, MA, USA)로 측정하였다.

갈변도는 양상추의 절단면을 잘게 자른 것을 무작위로 $2 \mathrm{~g}$ 취 하여 $20 \mathrm{~mL}$ 증류수를 가하고 water bath $\left(35^{\circ} \mathrm{C}\right)$ 에서 2 시간 동 안 추출한 뒤 여과한 액의 흡광도 $(420 \mathrm{~nm})$ 를 UV-Visible spectrophotometer (Optizen 2120UV, Mecasys Co., Ltd, Daejeon, Korea)로 측정하여 나타내었다(Jung 등, 2008).

\section{포장 내부 기체 분석}

저장 중 포장 내부의 산소 및 이산화탄소 농도는 포장 필름 표 면에 부착한 septum을 통해 가스분석기(Checkmate 3, PBI Dansensor Co, Ringsted, Denmark)와 연결된 실린지를 삽입하 여 측정하였다.

\section{총페놀 함량 및 DPPH radical 소거능 측정}

총페놀 함량 및 1,1-diphenyl-2-picryl hydrazyl (DPPH) 라디컬 소거능 분석용 시료는 양상추 $1.5 \mathrm{~g}$ 에 $80 \%$ 에탄올 $25 \mathrm{~mL}$ 을 가 하여 마쇄하고 1 시간 동안 추출, 여과한 여액을 사용하였다. 총 페놀함량은 Folin-Ciocalteu법(Singleton과 Rossi 1965)을 이용하 여 다음과 같이 측정하였다. 즉, 시료액 $0.4 \mathrm{~mL}$ 에 $2 \mathrm{~N}$ FolinCiocalteu 용액 $0.4 \mathrm{~mL}$ 를 첨가하여 3 분간 반응시킨 후 $2 \%$ $\mathrm{Na}_{2} \mathrm{CO}_{3} \quad 0.4 \mathrm{~mL}$ 를 가하고 암소에서 1 시간 방치하였다. 이 반응 액의 흡광도는 $760 \mathrm{~nm}$ 에서 측정하였으며, 이 때 UV-Visible Spectrophotometer (Optizen 2120UV, Mecasys Co., Ltd, Daejeon, Korea)를 이용하여 측정하였다. 이 때 시료에 함유된 총 페놀함 량은 gallic acid (Sigma Chemical Co., St. Louis, MO, USA) 를 표준품으로 하여 작성한 표준곡선으로부터 구하였다.

DPPH Radical 소거능 실험은 DPPH (Sigma Chemical Co.) 에 의한 전자공여능(electron donating ability)을 측정하였다 (Brand-Williams 등, 1995). 즉, $0.2 \mathrm{mM}$ 의 DPPH용액 $0.8 \mathrm{~mL}$ 에 시료액 $0.2 \mathrm{~mL}$ 를 첨가하여 혼합하고 실온에서 30 분간 반응 시킨 후 $517 \mathrm{~nm}$ 에서 흡광도를 측정하였다. 항산화력은 [1-(시 료첨가구의 흡광도/무첨가구의 흡광도) $] \times 100$ 의 계산식에 의해 전자공여능 $(\%)$ 을 구하였으며, 대조구는 시료 대신 메탄올을 첨 가하였다.

\section{미생물의 정량적 측정}

멸균백(sterile bags)에 시료 $10 \mathrm{~g}$ 씩을 넣고 $0.85 \% \mathrm{NaCl}$ 용액을 $90 \mathrm{~mL}$ 가하여 1 분간 교반한 후, $1 \mathrm{~mL}$ 씩 취하여 일반세균배지 (Petrifilm $^{\mathrm{TM}}$ aerobic count, $3 \mathrm{M}$, St. Paul, $\mathrm{MN}$, USA)에 각각 접종하였다. 접종 후 $35^{\circ} \mathrm{C}$ 에서 48 시간 배양한 후 colony 수를 측정하여 $\log$ colony forming unit $(\mathrm{CFU} / \mathrm{g})$ 으로 나타내었다. 각 각의 실험은 2 회 반복하였고 각 시료는 두 번 이상 채취하여 분석하였다.

\section{관능품질 평가}

신선편의 가공한 양상추의 저장 중 외관 및 냄새에 대한 관능 적 품질평가는 8 명의 훈련된 평가원을 대상으로 5 단계의 점수 ( 1 =매우 나쁨, 2 =나쁨, $3=$ 보통, $4=$ 좋음, $5=$ 매우 좋음)를 부 여하였으며 점수 3 점을 상품성의 한계로 간주하였다.

\section{통계처리}

실험은 반복 실시하였으며, 유의성 검증을 위하여 SPSS version 12 (SPSS Institute, Chicago, IL, USA)를 이용하여 ANOVA analysis와 Duncan's multiple range test 및 Pearson의 상관관 계분석으로 $5 \%$ 수준에서 유의성을 분석하였다.

\section{결과 및 고찰}

\section{신선편의 양상추의 저장 중 표면온도 및 중량감소율 변화}

신선편의 양상추를 저온 저장 $\left(10^{\circ} \mathrm{C}\right)$ 한 경우 표면온도의 변화는 Fig. $1 \mathrm{~A}$ 와 같이 평균 $13{ }^{\circ} \mathrm{C}$ 내외였다. 필름의 산소투과율 및 저 장일에 따른 통계적 유의차는 나타나지 않았으나, 동일한 온도 

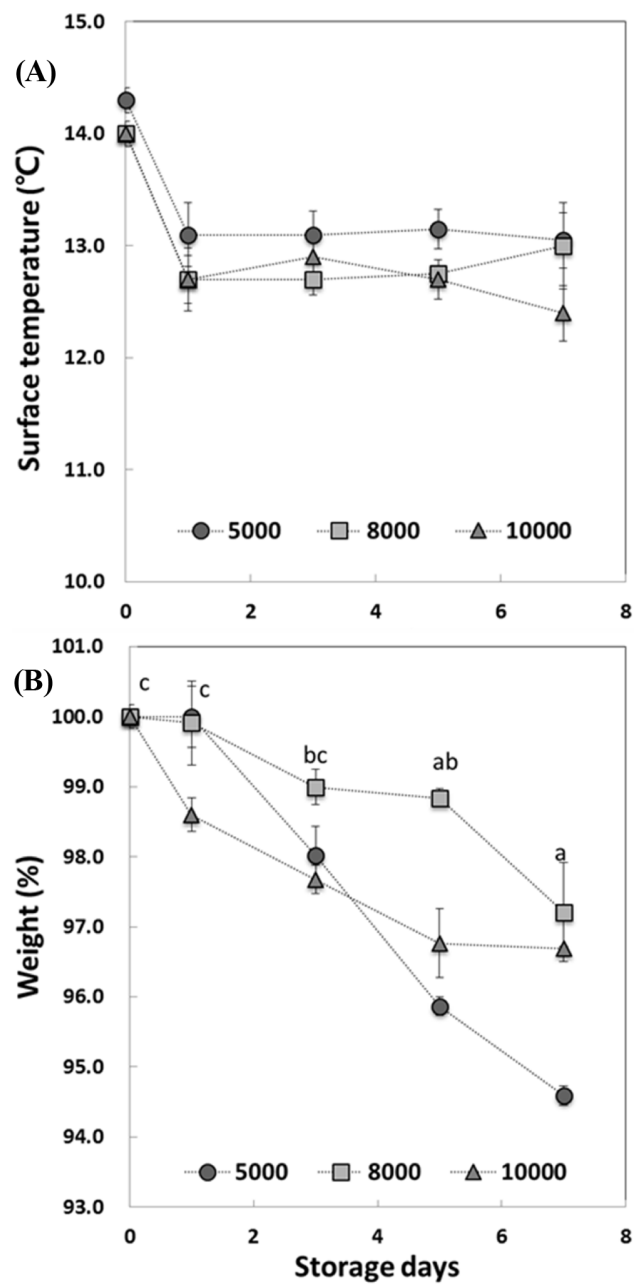

Fig. 1 Surface temperature (A) and weight loss (B) of fresh-cut lettuce with different oxygen transmission permeability (OTR) of films during storage $\left(10{ }^{\circ} \mathrm{C}\right.$ for 7 days $)$. - -; OTR $=5,000 \mathrm{cc} / \mathrm{m}^{2} \cdot$ day $\cdot$ atm, $-\boldsymbol{-}-$; OTR $=8,000 \mathrm{cc} / \mathrm{m}^{2} \cdot$ day $\cdot$ atm, $-\mathbf{\Lambda}-;$ OTR $=10,000 \mathrm{cc} / \mathrm{m}^{2} \cdot$ day $\cdot$ atm, a,b,c: Different letters within a row are significantly different $p<0.05$ by Duncan's multiple range test. Vertical lines represent Mean \pm SD $(n=3)$

조건에서 보관하였음에도 필름의 산소투과율이 높을수록 표면 온도는 낮게 유지되고 있었는데, 투과율 $5,000 \mathrm{cc} / \mathrm{m}^{2} \cdot \mathrm{day} \cdot \mathrm{atm}$ $(\mathrm{O} 5)$ 에서는 평균 $13.3^{\circ} \mathrm{C}, 8,000 \mathrm{cc} / \mathrm{m}^{2} \cdot \mathrm{day} \cdot \mathrm{atm}(\mathrm{O})$ 의 평균은 $13.0^{\circ} \mathrm{C}, 10,000 \mathrm{cc} / \mathrm{m}^{2} \cdot \mathrm{day} \cdot \mathrm{atm}(\mathrm{O} 10)$ 에서는 $12.9^{\circ} \mathrm{C}$ 였다. 이러 한 경향은 쌈채소류에 대한 가스치환포장 연구에서도 유사하게 나타났는데, 초기산소함량이 높을수록 평균 표면온도가 낮게 나 타났다(결과 미제시). MAP를 적용한 신선편의 식품의 저온관 리는 제품의 품질에 매우 큰 영향을 미치므로 $4^{\circ} \mathrm{C}$ 이하의 저 온유지가 권장되고 있는데, 온도가 증가할수록 필름의 투과도도 증가하여 내부기체 조성 변화로 인한 품질열화가 발생하는 것 으로 알려져 있다(Cliffe-Byrnes 등, 2003). 본 연구에서도 동일 저장온도 하에서도 서로 다른 필름의 투과율과 이로 인한 기체 조성의 차이로 인해 표면온도가 상이하게 나타내는 것으로 판 단된다. 국내 냉장 유통환경은 $4{ }^{\circ} \mathrm{C}$ 이하의 저온을 유지하기 어 렵고, 저장온도보다 제품의 품온이 높아질 수 있으며, 이에 따
른 기체조성의 변화, 미생물 증식 등 품질에 영향을 미칠 것으 로 예측되므로, 유통환경 관리 시 고려해야 할 것이다.

신선편의 양상추의 저장 중 중량감소율은 다음의 Fig. $1 \mathrm{~B}$ 와 같이 필름의 산소투과율에 따른 유의차는 없었으나, 저장일에 따른 유의차가 나타나고 있었다 $(p<0.05)$. 모든 처리구에서 저장 7일차의 중량감소율은 $2.8-5.4 \%$ 수준으로 나타나, 일반적인 엽 채류 저장시의 생체중감소 범위인 $3 \sim 5 \%$ 에 해당하였다(Kays와 Paull 2004). 저장일 경과에 따른 중량감소율은 저장 $1,3,5,7$ 일 모두에서 유의적인 차이를 나타내었다 $(p<0.05)$. 저장 1 일까 지는 $\mathrm{O} 10$ 의 중량감소가 가장 컸고, 이후 저장후기로 갈수록 5000 이 가장 크게 나타났다. 저장 중 중량감소가 가장 낮았던 구는 $\mathrm{O} 8$ 으로 나타났다. 신선 과일 및 채소류의 저장 시 호흡 및 증산작용으로 인해 수분 손실이 일어나고 이에 따른 조직연 화 및 중량감소가 발생하며(Kays와 Paull 2004), 저온저장 및 기체치환포장에 따라 중량감소 등의 변화를 감소시키는 것으로 알려져 있다(Martýnez와 Artes 1999). 본 연구에서도 산소투과 율에 따른 포장 내부 기체조성의 변화로 인해 중량감소율이 저 장일 경과에 따라 유의적인 차이를 나타내는 것으로 판단된다. 저장 1 일, $3,5,7$ 일 모두 유의적인 차이가 있었으며, 저장 1 일 까지는 $\mathrm{O} 10$ 의 중량감소가 가장 컸고, 이후 저장후기로 갈수록 5000 이 가장 크게 나타났다. O8의 중량감소가 가장 낮았다.

\section{신선편의 양상추의 저장 중 이화학적 품질 변화}

신선편의 양상추의 저장 중 $\mathrm{pH}$ 변화는 Table 1 과 같다. 저장일 의 경과에 따라 $\mathrm{pH}$ 는 유의적으로 증가하고 있었으며 $(p<0.05)$, 필름의 산소투과율에 따른 유의적 차이는 나타나지 않았다. 다 만 산소투과율이 높을수록 $\mathrm{pH}$ 의 변화는 작게 나타나 저장 7일 경 $\mathrm{pH}$ 는 $\mathrm{O} 5$ 에서 $6.63, \mathrm{O} 8$ 에서 $6.51, \mathrm{O} 10$ 에서 6.34 로 나타났 다. 이러한 $\mathrm{pH}$ 의 변화는 일반적인 신선편의 가공 채소류의 $\mathrm{pH}$ 범위인 5.8 6.5와 일치하였으며, 이른바 wounding theory로 인 한 식물생리학적 변화로 인해 발생하는 것으로 보고되어 있으 며(Ahvenainen 1996) 항균필름으로 포장한 신선편의 양상추의

Table 1 Changes in $\mathrm{pH}$ and browning index of fresh-cut lettuce with different oxygen transmission permeability (OTR) of films during storage at $10^{\circ} \mathrm{C}$ for 7 days

\begin{tabular}{ccccc}
\hline \hline \multirow{2}{*}{ Variable } & \multirow{2}{*}{$\begin{array}{c}\text { Storage } \\
\text { days }\end{array}$} & \multicolumn{3}{c}{$\mathrm{O}_{2}$ transmission rate $(\mathrm{OTR})$} \\
\cline { 2 - 5 } & 0 & $\mathrm{O}^{1)}$ & $\mathrm{O} 8$ & $\mathrm{O} 10$ \\
\hline \multirow{3}{*}{$\mathrm{pH}$} & 1 & $\left.6.13 \pm 0.03^{\mathrm{a} 2}\right)$ & $6.13 \pm 0.03^{\mathrm{a}}$ & $6.13 \pm 0.06^{\mathrm{a}}$ \\
& 3 & $6.50 \pm 0.07^{\mathrm{b}}$ & $6.28 \pm 0.00^{\mathrm{a}}$ & $6.28 \pm 0.04^{\mathrm{a}}$ \\
& 5 & $6.63 \pm 0.03^{\mathrm{b}}$ & $6.52 \pm 0.01^{\mathrm{b}}$ & $6.46 \pm 0.01^{\mathrm{b}}$ \\
& 7 & $6.63 \pm 0.03^{\mathrm{b}}$ & $6.51 \pm 0.06^{\mathrm{b}}$ & $6.34 \pm 0.02^{\mathrm{b}}$ \\
& 0 & $0.07 \pm 0.02^{\mathrm{a}}$ & $0.07 \pm 0.02^{\mathrm{a}}$ & $0.07 \pm 0.02^{\mathrm{a}}$ \\
Browning & 1 & $0.07 \pm 0.05^{\mathrm{a}}$ & $0.08 \pm 0.00^{\mathrm{a}}$ & $0.10 \pm 0.01^{\mathrm{a}}$ \\
index & 3 & $0.10 \pm 0.13^{\mathrm{a}}$ & $0.10 \pm 0.09^{\mathrm{a}}$ & $0.20 \pm 0.05^{\mathrm{a}}$ \\
& 5 & $0.29 \pm 0.18^{\mathrm{b}}$ & $0.19 \pm 0.20^{\mathrm{b}}$ & $0.27 \pm 0.02^{\mathrm{b}}$ \\
& 7 & $0.41 \pm 0.01^{\mathrm{b}}$ & $0.21 \pm 0.04^{\mathrm{b}}$ & $0.29 \pm 0.07^{\mathrm{b}}$ \\
\hline
\end{tabular}

Values are the means of triplicate \pm standard deviation.

${ }^{1)} \mathrm{O} 5$ : OTR $=5,000 \mathrm{cc} / \mathrm{m}^{2} \cdot$ day $\cdot$ atm, O8: OTR $=5,000 \mathrm{cc} / \mathrm{m}^{2} \cdot$ day $\cdot \mathrm{atm}, \mathrm{O} 10$ : $\mathrm{OTR}=10,000 \mathrm{cc} / \mathrm{m}^{2} \cdot \mathrm{day} \cdot \mathrm{atm}$

${ }^{2)}$ Values means with different letters are significantly different at $p<0.05$ by Duncan's multiple range test 
$\mathrm{pH}$ 변화는 부패율과 밀접한 관련이 있었다(Kang 등, 2007). 본 연구결과에서도 저장 5 일 이후 $\mathrm{pH}$ 변화가 크게 나타난 경우 짓 무름 등 부패가 진행되고 있었다.

서로 다른 산소투과율에 따른 갈변도의 변화는 Table 1 과 같 다. 산소투과율에 따른 유의적 차이는 나타나지 않았으나, 저장 1,3 일까지와 그 이후로 저장일 경과에 따른 유의적 차이를 나 타내고 있었다 $(p<0.05)$. 저장 초기에는 산소투과율이 높은 $\mathrm{O} 10$ 의 갈변도가 가장 크게 증가하였으나, 저장후기로 갈수록 투과 율이 낮은 $\mathrm{O} 5$ 의 갈변도가 가장 크게 나타났다. 신선편의 과일 및 채소의 갈변은 절단 등 가공과정에서 양상추 조직 상해로 인한 페놀성 물질의 축적과 이로 인한 효소적 갈변 반응으로 인해 발생하는 것으로 알려져 있다(Tomas-Barberan 등, 1997). 이러한 효소적 갈변반응에서 산소와 온도는 매우 중요한 조건 으로, 본 연구결과에서도 저장 초기 갈변 반응의 필수요소인 산 소의 함량이 높은 처리구에서 갈변도가 크게 증가한 것으로 판 단된다. 이는 Kim 등(2005)의 연구에서도 유사한 경향을 나타 냈는데, 초기 산소함량이 높고 산소투과율이 높은 필름으로 포 장한 로메인 상추의 갈변이 더 크게 나타났다. 한편 저장 후기 의 갈변도는 효소적 갈변 반응 외 짓무름과 초기부패로 인한 증가인 것으로 생각되며, 가장 먼저 짓무르기 시작한 $\mathrm{O} 5$ 의 갈 변도가 가장 높게 나타났다.

\section{저장 중 기체 조성 변화}

신선편의 양상추의 저장 중 기체조성 변화는 다음의 Fig. 2와 같이 저장일 경과에 따라 산소는 감소하고, 이산화탄소는 증가 하고 있었다. 다른 품질특성과 마찬가지로 필름의 산소투과율에 따른 유의적 차이는 나타나지 않았으나, 산소투과율이 높을수록 잔존산소 함량이 높고, 이산화탄소 함량이 낮게 나타났다. 저장 일 경과에 따라 산소함량의 감소 및 이산화탄소 함량의 증가가 유의적으로 나타났는데 $(p<0.05)$ (Fig. 2$)$, 이러한 변화는 신선편 의 가공에 의해 나타나는 일반적인 현상으로, 절단 등 가공으 로 인한 호흡증가가 그 원인으로 보고되고 있다(Brecht 1995). 신선편의 로메인 상추를 대상으로 한 $\mathrm{Kim}$ 등(2005)의 보고에 서도 필름의 산소투과율이 높고 초기 산소함량이 높은 경우 저 장 중 포장 내부의 산소함량이 높게 유지되고 있었으며, 이산 화탄소 함량은 가장 낮게 축적되고 있었다. 신선편의 식품에 $\mathrm{MAP}$ 를 적용할 경우 초기 저산소 조건을 형성하여 호흡율을 감 소시키고 이를 통한 유통기한 연장을 기대할 수 있다. 한편 $1 \%$ 미만의 산소 함량은 혐기적 호흡으로 인한 이취발생을 유발할 수 있는데(Smyth 등, 1988), 본 연구에서는 저장 7일경 모든 처리구에서 $5 \%$ 이상의 잔존산소를 유지하고 있었다(Fig. 2A). 이는 포장 시 대기 수준 $(21 \%)$ 의 산소 함량이었기 때문으로 판 단되며, 혐기 상태에 이르는 것을 방지할 수는 있으나 초기 갈 변을 방지하기 어렵다. 따라서 신선편의 식품에 MAP를 적용할 경우, 저장 중 포장 내부가 혐기 상태에 이르지 않도록 초기 산 소함량을 $10 \%$ 이하로 조정 및 필름의 산소투과율을 목표 유통 기한에 맞추어 미세하게 조정하는 것이 매우 중요하다(Smyth 등, 1988).

\section{신선편의 양상추의 저장 중 총페놀 및 항산화성의 변화}

저장에 따른 신선편의 양상추의 총페놀 함량변화는 Fig. $3 \mathrm{~A}$ 와 같이 저장일 경과에 따라 유의적으로 감소하였으며, 필름의 산
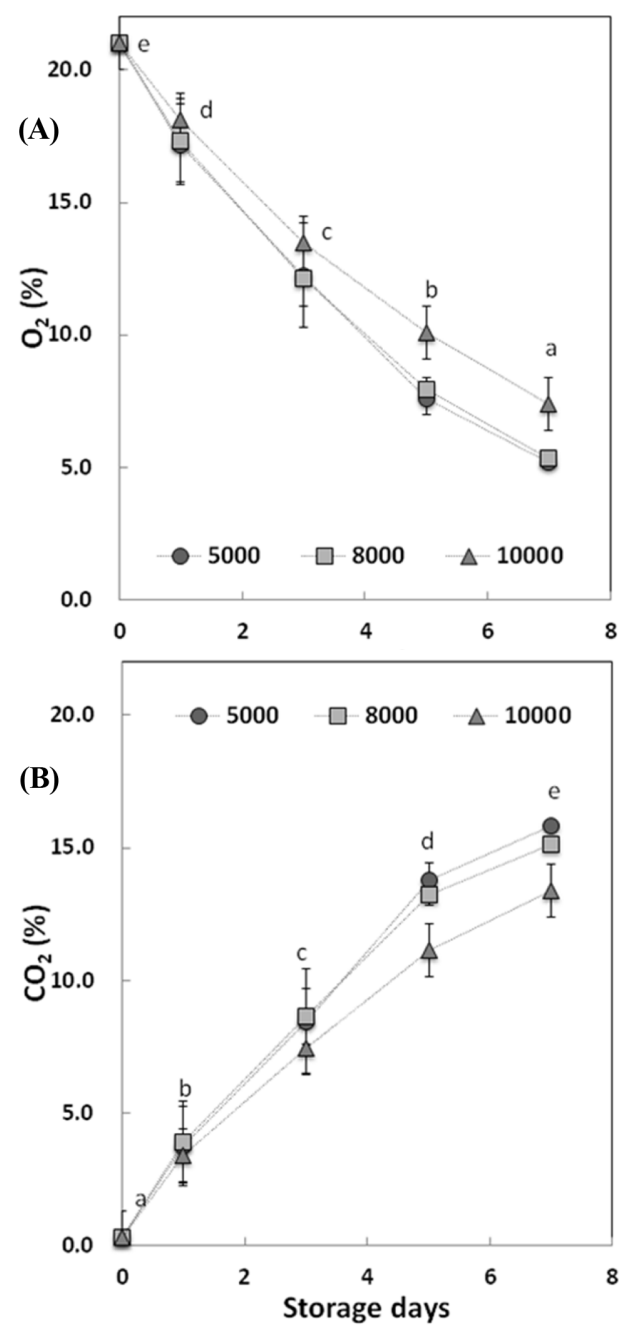

Fig. 2 Changes in $\mathrm{O}_{2}(\mathrm{~A})$ and $\mathrm{CO}_{2}$ (B) of fresh-cut lettuce with different oxygen transmission permeability (OTR) of films during storage $\left(10^{\circ} \mathrm{C}\right.$ for 7 days). - -; OTR $=5,000 \mathrm{cc} / \mathrm{m}^{2} \cdot$ day $\cdot \mathrm{atm},-\mathbf{\square}-;$ OTR $=8,000 \mathrm{cc} /$ $\mathrm{m}^{2} \cdot$ day $\cdot \mathrm{atm},-\boldsymbol{\Delta}-;$ OTR $=10,000 \mathrm{cc} / \mathrm{m}^{2} \cdot$ day $\cdot$ atm, a,b,c: Different letters within a row are significantly different $p<0.05$ by Duncan's multiple range test. Vertical lines represent Mean $\pm \operatorname{SD}(n=3)$

소투과율에 따른 통계적 유의차는 나타나지 않았다 $(p<0.05)$. 저 장 초기 총페놀 함량은 급격히 감소하여, 저장 1 일경 양상추의 총페놀 함량은 $\mathrm{O} 5$ 에서 $174.53 \mathrm{mg} / 100 \mathrm{~g}$, O8에서 $250.33 \mathrm{mg} /$ $100 \mathrm{~g}$ 및 $\mathrm{O} 10$ 에서 $269.00 \mathrm{mg} / 100 \mathrm{~g}$ 까지 감소하였다. 이는 서로 다른 품종의 양상추를 15 일간 저장하면서 페놀함량의 변화를 조사한 Serea 등(2014)의 보고와도 유사하였다. 수확 후 식물체 의 페놀 성분 증가는 외부 상해나 미생물 오염에 대응하기 위 한 것으로 보고되고 있다(Dixon과 Paiva 1995; Pereira 등, 2014). 총페놀 함량은 저장온도에 의해서도 영향을 받는 것으로 알려져 있는데, 저장 온도가 낮을수록 총페놀 함량이 높게 유 지되고 있었다(Serea 등, 2014). 온도는 호흡, 효소활성 등 식물 의 생리작용에 영향을 주어 온도가 높을 경우 생리반응으로 인 한 polyphenol 물질의 분해가 더 활발히 일어나기 때문으로 보 고되고 있다(Boo 등, 2011). 즉, 신선편의 양상추의 저장에 따 

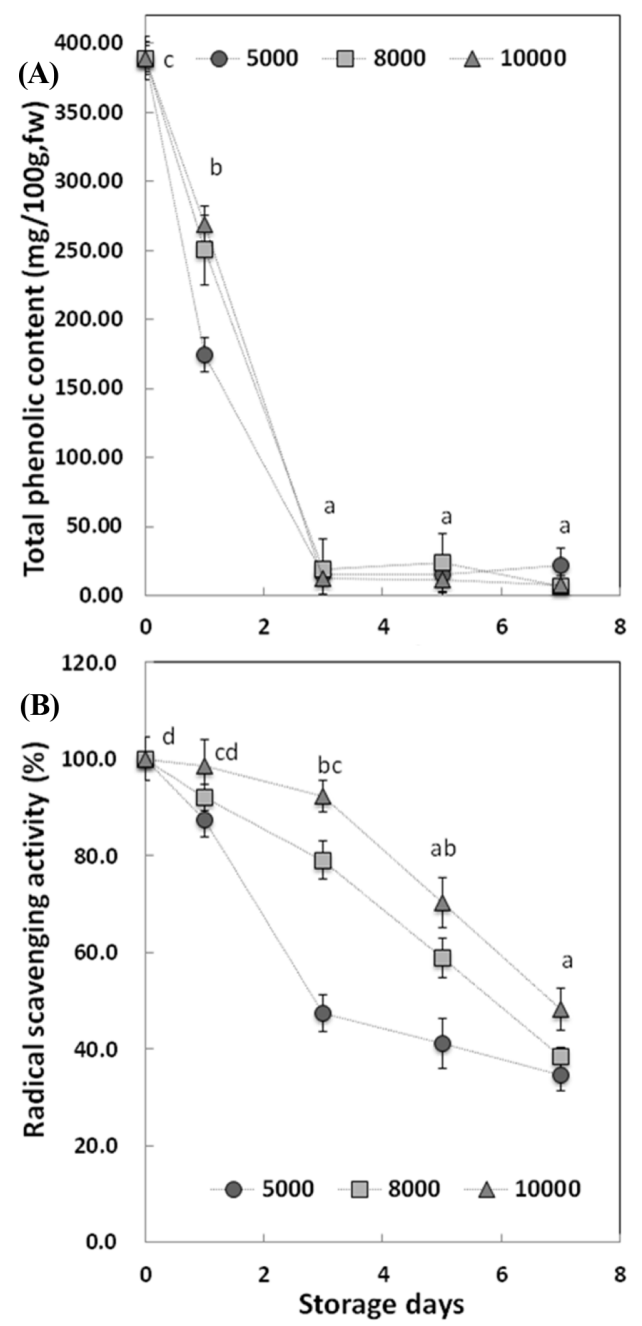

Fig. 3 Changes in total phenolic content (A) and DPPH radical scavenging ability (B) of fresh-cut lettuce with different oxygen transmission permeability (OTR) of films during storage $\left(10^{\circ} \mathrm{C}\right.$ for 7 days). - -; OTR $=5,000 \mathrm{cc} / \mathrm{m}^{2} \cdot$ day $\cdot \mathrm{atm},-\mathbf{\square}$-; OTR=8,000 $\mathrm{cc} / \mathrm{m}^{2} \cdot$ day . atm, - $\mathbf{\Lambda}$-; OTR $=10,000 \mathrm{cc} / \mathrm{m}^{2} \cdot$ day $\cdot$ atm, a,b,c: Different letters within a row are significantly different $p<0.05$ by Duncan's multiple range test. Vertical lines represent Mean $\pm \mathrm{SD}(\mathrm{n}=3)$

라 갈변도를 나타내며 총페놀 함량이 감소하고 있었으나, 저장 3일까지는 산소투과율이 높은 처리구에서 상대적으로 높은 총 페놀 함량을 유지하고 있었던 것은 표면 온도는 더 낮게 유지 할 수 있었기 때문으로 생각된다.

신선편의 양상추의 저장에 따른 항산화성 변화는 $\mathrm{DPPH}$ radical 소거능으로, 저장에 따라 유의적 감소를 나타내어, 저장 7일경 $\mathrm{DPPH}$ radical 소거능은 $\mathrm{O} 5$ 에서 $34.7 \%, \mathrm{O}$ 에서 $38.5 \%$ 및 $\mathrm{O} 10$ 에서 $48.2 \%$ 로 나타났다(Fig. $3 \mathrm{~B})$. 한편 필름의 산소투과 율에 따른 유의적 차이는 나타나지 않았으나 산소투과율이 높 을수록 항산화성도 높게 유지되고 있었다.

양상추는 flavonoids, phenolic acids 및 ascorbic acid가 풍 부하여 항산화능을 나타내는 것으로 알려져 있으며, 저장 중 채 소류의 항산화성 변화는 다양한 성분 간의 상호작용으로 인해
Table 2 Changes in microbiological qualities (log CFU/g) of fresh-cut lettuce with different oxygen transmission permeability (OTR) of films during storage at $10^{\circ} \mathrm{C}$ for 7 days

\begin{tabular}{ccccc}
\hline \hline \multirow{2}{*}{$\begin{array}{c}\text { Micro- } \\
\text { organism }\end{array}$} & \multirow{2}{*}{$\begin{array}{c}\text { Storage } \\
\text { days }\end{array}$} & \multicolumn{3}{c}{$\mathrm{O}_{2}$ transmission rate (OTR) } \\
\cline { 2 - 5 } & & $\mathrm{O}^{1)}$ & $\mathrm{O} 8$ & $\mathrm{O} 10$ \\
\hline & 0 & $3.53 \pm 0.12^{\mathrm{a}}$ & $3.53 \pm 0.12^{\mathrm{a}}$ & $3.53 \pm 0.12^{\mathrm{a}}$ \\
Total aerobic & 1 & $4.72 \pm 0.21^{\mathrm{a}}$ & $3.00 \pm 0.19^{\mathrm{a}}$ & $3.60 \pm 0.20^{\mathrm{a}}$ \\
bacteria & 3 & $5.01 \pm 0.17^{\mathrm{b}}$ & $4.72 \pm 0.16^{\mathrm{b}}$ & $5.00 \pm 0.12^{\mathrm{b}}$ \\
$(\log$ CFU/g) & 5 & $4.97 \pm 0.19^{\mathrm{b}}$ & $5.81 \pm 0.25^{\mathrm{b}}$ & $6.45 \pm 0.15^{\mathrm{b}}$ \\
& 7 & $5.48 \pm 0.25^{\mathrm{b}}$ & $5.74 \pm 0.30^{\mathrm{b}}$ & $6.59 \pm 0.35^{\mathrm{b}}$ \\
\hline
\end{tabular}

Values are the means \pm standard deviation

${ }^{1)} \mathrm{O} 5$ : OTR $=5,000 \mathrm{cc} / \mathrm{m}^{2} \cdot$ day $\cdot \mathrm{atm}, \mathrm{O} 8: \mathrm{OTR}=5,000 \mathrm{cc} / \mathrm{m}^{2} \cdot$ day $\cdot \mathrm{atm}, \mathrm{O} 10$ : OTR $=10,000 \mathrm{cc} / \mathrm{m}^{2} \cdot$ day $\cdot$ atm

${ }^{2)}$ Values means with different letters are significantly different at $p<0.05$ by Duncan's multiple range test

나타나기 때문에 단순하게 설명하기는 어렵다(Pereira 등, 2014). 다만 본 연구결과에서는 총페놀 함량과 항산화성분간의 상관관 계가 0.8 수준(Table 4)으로 높게 나타나 양상추의 총페놀 함량 이 가공 및 저장으로 인해 감소하면서 항산화성도 함께 감소한 것으로 판단된다. 본 연구결과와 유사하게 서로 다른 품종의 양 상추에서도 저장일에 따라 항산화성이 감소하였으며, 저장온도 가 낮을수록 그 감소폭이 작게 나타났다. 이는 총페놀 함량과 긴밀하게 연관되어 있었다(Serea 등, 2014).

\section{저장 중 신선편의 양상추의 미생물 및 관능적 품질 변화}

신선편의 양상추의 일반세균 변화는 Table 2 와 같이 저장일에 따른 유의적 차이를 나타내고 있었다 $(p<0.05)$. 일반세균은 초기 $3.53 \log \mathrm{CFU} / \mathrm{g}$ 수준에서 저장 7일경 5.48 6.59 $\log \mathrm{CFU} / \mathrm{g}$ 수준으로 증식하였는데, 산소투과율이 높을수록 높게 나타났다. 산소투과율이 높은 필름으로 포장할수록 잔존산소 함량이 높았 고 이에 따라 저장 후기의 일반세균이 높게 나타나고 있는 것 으로 판단된다. 즉, 포장 내 잔존 산소함량에 의해 증식이 지속 될 수 있는 점을 감안한다면 유통기한을 고려한 초기 균수의 관리 및 온도관리 등이 매우 중요할 것이므로(19), 가공 및 유 통 시 초기 균수 및 온도 등을 중요 인자로 관리해야 할 것으 로 생각된다(Panisello와 Quantick 1998).

저장 중 신선편의 양상추의 관능적 품질 변화는 Table 3 과 같이 나타났다. 모든 처리구에서 저장 7일까지 이취는 거의 발 생하지 않았으나, 절단면의 갈변으로 인해 저장 3 일경부터 급 격한 외관 품질의 저하를 나타내었다. 단, 절단면의 갈변이 균 일하지 않아 편차가 크게 나타나는 경향이 있었으며, 산소투과 율에 따른 유의적 차이는 나타나지 않았다 $(p<0.05)$. 또한 절단 면의 갈변도와 외관품질은 높은 수준의 음의 상관관계를 나타 내고 있었다(-8.7)(Table 4). 외관의 경우 O8 및 $\mathrm{O} 10$ 중 산소 투과도가 낮은 처리구에서 3.8 의 점수를 나타내어, 갈변 방지를 위해서는 $\mathrm{O} 8$ 이 유리할 것으로 판단된다. 저장에 따른 신선편의 양상추 제품의 전반기호도를 기준으로 저장 5 일경까지 $\mathrm{O} 8$ 및 $\mathrm{O} 10$ 에서 3.0 이상의 상업적 품질을 유지하고 있었다. 이러한 결 과를 바탕으로 산소투과도 $8,000 \mathrm{cc} / \mathrm{m}^{2} \cdot \mathrm{day} \cdot \mathrm{atm}$ 이상, 평균온도 $10{ }^{\circ} \mathrm{C}$ 이하로 관리할 경우 냉장 5 일 이상의 유통기한 유지가 가 능할 것으로 판단된다. 
Table 3 Changes in sensory quality of fresh-cut lettuce with different oxygen transmission permeability (OTR) of films during storage at $10{ }^{\circ} \mathrm{C}$ for 7 days

\begin{tabular}{ccccc}
\hline \hline \multirow{2}{*}{$\begin{array}{c}\text { Sensory } \\
\text { quality }\end{array}$} & \multirow{2}{*}{$\begin{array}{c}\text { Storage } \\
\text { days }\end{array}$} & \multicolumn{3}{c}{$\mathrm{O}_{2}$ transmission rate (OTR) } \\
\cline { 2 - 5 } & 0 & $5.0 \pm 0.0^{\mathrm{b} 2)}$ & $5.0 \pm 0.0^{\mathrm{b}}$ & $5.0 \pm 0.0^{\mathrm{b}}$ \\
\hline & 1 & $5.0 \pm 0.0^{\mathrm{b}}$ & $5.0 \pm 0.0^{\mathrm{b}}$ & $5.0 \pm 0.0^{\mathrm{b}}$ \\
Overall & 3 & $4.0 \pm 0.2^{\mathrm{b}}$ & $4.5 \pm 0.7^{\mathrm{b}}$ & $4.5 \pm 0.7^{\mathrm{b}}$ \\
acceptability & 5 & $3.0 \pm 1.4^{\mathrm{a}}$ & $3.0 \pm 1.4^{\mathrm{a}}$ & $4.0 \pm 0.1^{\mathrm{a}}$ \\
& 7 & $2.1 \pm 1.4^{\mathrm{a}}$ & $2.5 \pm 2.1^{\mathrm{a}}$ & $3.5 \pm 0.7^{\mathrm{a}}$ \\
\hline \multirow{4}{*}{ Appearance } & 0 & $5.0 \pm 0.0^{\mathrm{c}}$ & $5.0 \pm 0.0^{\mathrm{c}}$ & $5.0 \pm 0.0^{\mathrm{c}}$ \\
& 1 & $5.0 \pm 0.3^{\mathrm{c}}$ & $5.0 \pm 0.5^{\mathrm{c}}$ & $5.0 \pm 0.4^{\mathrm{c}}$ \\
& 3 & $3.5 \pm 0.2^{\mathrm{b}}$ & $4.0 \pm 1.4^{\mathrm{b}}$ & $3.5 \pm 0.7^{\mathrm{b}}$ \\
& 5 & $2.5 \pm 0.7^{\mathrm{b}}$ & $3.8 \pm 1.1^{\mathrm{b}}$ & $3.3 \pm 0.4^{\mathrm{b}}$ \\
& 7 & $1.5 \pm 0.7^{\mathrm{a}}$ & $2.6 \pm 1.4^{\mathrm{a}}$ & $2.5 \pm 0.7^{\mathrm{a}}$ \\
\hline \multirow{5}{*}{ Odor } & 0 & $5.0 \pm 0.0$ & $5.0 \pm 0.0$ & $5.0 \pm 0.0$ \\
& 1 & $5.0 \pm 0.0$ & $5.0 \pm 0.0$ & $5.0 \pm 0.0$ \\
& 3 & $4.5 \pm 0.5$ & $4.5 \pm 0.0$ & $5.0 \pm 0.0$ \\
& 5 & $4.5 \pm 0.7$ & $4.5 \pm 0.7$ & $5.0 \pm 0.0$ \\
& 7 & $4.5 \pm 0.7$ & $4.5 \pm 0.7$ & $5.0 \pm 0.0$ \\
\hline
\end{tabular}

Values are the means \pm standard deviation

${ }^{1)} \mathrm{O} 5$ : OTR $=5,000 \mathrm{cc} / \mathrm{m}^{2} \cdot$ day $\cdot$ atm, O8: OTR $=5,000 \mathrm{cc} / \mathrm{m}^{2} \cdot$ day $\cdot \mathrm{atm}, \mathrm{O} 10$ : OTR $=10,000 \mathrm{cc} / \mathrm{m}^{2} \cdot$ day $\cdot \mathrm{atm}$

${ }^{2)}$ Values means with different letters are significantly different at $p<0.05$ by Duncan's multiple range test

산소투과율에 따른 저장 중 신선편의 양상추의 품질 간 상관관계 신선편의 식품의 저장 중 품질변화의 기작을 단순하게 설명하 기 어렵기 때문에, 다음의 Table 4 와 같이 투과율에 따른 신선 편의 양상추의 품질 결과 간의 상관관계를 조사하였다. 품질 지 표 중 중량감소율의 경우 이산화탄소, $\mathrm{pH}$, 갈변도 및 일반세균 수의 변화와 음의 상관관계 $(p<0.01)$ 를 나타내었는데, 이는 신선 편의 가공에 의한 양상추의 식물생리학적 변화에 따른 결과로 보여진다. 저장 중 양상추의 항산화성은 총페놀 함량과 0.868 의 높은 상관관계를 나타내었고, 일반세균수는 관능품질과 높은 음 의 상관관계를 나타내었다. 특히 포장 내 기체조성의 변화 중 산소 함량은 관능품질 및 총페놀 함량, DPPH 라디칼 소거능과
매우 높은 양의 상관관계를 나타내었다(>0.9). 한편 이산화탄소 함량은 일반세균수, $\mathrm{pH}$, 갈변도와 높은 양의 상관관계를 나타 내었다 $(>0.8)$. 이러한 결과는 신선편의 양상추의 저장 중 품질 변화는 포장 필름의 산소투과율에 따른 통계적 유의차를 나타 내지 않았으나, 포장 내부의 기체조성은 신선편의 식품의 품질 에 영향을 미치며 이를 통제하기 위한 기체치환포장 및 다양한 투과율의 필름의 적용 가능성을 나타내는 결과이다. 특히 본 연 구결과에서 산소투과율에 따른 통계적 유의차가 나타나지 않은 것은, 동일한 포장필름을 적용하고 산소투과율의 차이가 크지 않기 때문으로 판단되나, 품질 유지에 가장 유효한 산소투과도 범위를 확인하는 것은 실제 상업적 적용 및 품질관리에 매우 유용한 기초자료가 될 것이다.

\section{초 록}

신선편의 양상추의 포장 시 산소투과율이 서로 다른 필름을 적 용하여 저온저장 중 품질 변화를 조사하여 신선편의 식품의 제 품설계 및 유통 중 품질 관리를 위한 기초 자료로 활용하고자 하였다. 신선편의 양상추는 산소투과율 각각 $5,000,8,000$ 및 $10,000 \mathrm{cc} / \mathrm{m}^{2} \cdot \mathrm{day} \cdot \mathrm{atm}$ 인 OPP 필름을 리드로 하여 용기 포장하 고 $10^{\circ} \mathrm{C}$ 에서 7 일간 저장하면서 품질변화를 조사하였다. 필름의 산소투과율에 따른 통계적 유의차는 나타나지 않았으나, 표면온 도를 제외하고 모든 품질 항목이 저장일 경과에 따른 통계적 유의차를 나타내었다 $(p<0.05)$. 저장 중 신선편의 양상추의 표면 온도는 평균 $13{ }^{\circ} \mathrm{C}$ 내외로, 산소투과율이 높을수록 표면온도는 낮게 유지되고 있었다. 저장 7일경 중량감소율은 $2.8 ~ 5.4 \%$ 수 준으로 산소투과율 $5,000 \mathrm{cc} / \mathrm{m}^{2} \cdot \mathrm{day} \cdot \mathrm{atm}$ 에서 가장 높았다. $\mathrm{pH}$ 는 저장에 따라 유의적으로 증가하였으며 $(p<0.05)$, 산소투과율 이 높을수록 $\mathrm{pH}$ 의 변화는 작았다. 저장에 따라 포장 내부의 산 소는 감소하고, 이산화탄소는 증가하고 있었는데, 필름의 산소 투과율이 높을수록 잔존산소 함량이 높고, 이산화탄소 함량이 낮게 나타났다. 저장에 따른 총페놀 함량 및 DPPH 라디칼 소 거능은 감소하고 있었는데, 필름의 산소투과율이 높을수록 총페 놀 및 항산화성도 높게 유지되고 있었다. 저장 7일경 일반세균 은 5.48 6.59 $\log \mathrm{CFU} / \mathrm{g}$ 수준으로, 산소투과율이 높을수록 높

Table 4 Correlation coefficients among different variables of fresh-cut lettuce during storage at $10{ }^{\circ} \mathrm{C}$ for 7 days

\begin{tabular}{|c|c|c|c|c|c|c|c|c|c|c|c|}
\hline & Weight $^{1)}$ & $\mathrm{O}_{2}$ & $\mathrm{CO}_{2}$ & $\mathrm{pH}$ & BI & $\mathrm{TP}$ & TVC & DPPH & App & Odor & Overall \\
\hline Weight & 1.000 & $0.836^{* * 2)}$ & $-0.846^{* *}$ & $-0.802 * *$ & $-0.947 * *$ & $0.719^{* *}$ & $-0.890 * *$ & $0.854 * *$ & $0.884 * *$ & $0.574 *$ & $0.828 * *$ \\
\hline $\mathrm{O}_{2}$ & & 1.000 & $-0.999 * *$ & $-0.891 * *$ & $-0.840 * *$ & $0.906^{* *}$ & $-0.906^{* *}$ & $0.854 * *$ & $0.959 * *$ & $0.713 * *$ & $0.927 * *$ \\
\hline $\mathrm{CO}_{2}$ & & & 1.000 & $0.894 * *$ & $0.853^{* *}$ & $-0.898 * *$ & $0.914 * *$ & $-0.859^{* *}$ & $-.0957 * *$ & $-0.725^{* *}$ & $-0.931 * *$ \\
\hline $\mathrm{pH}$ & & & & 1.000 & $0.725^{* *}$ & $-0.885^{* *}$ & $0.894 * *$ & $-0.899 * *$ & $-0.869^{* *}$ & $-0.692 * *$ & $-0.824 * *$ \\
\hline BI & & & & & 1.000 & $-0.681 * *$ & $0.850^{* *}$ & $-0.888^{* *}$ & $-0.867 * *$ & $-0.621 * *$ & $-0.847 * *$ \\
\hline $\mathrm{TP}$ & & & & & & 1.000 & $-0.797 * *$ & $0.868 * *$ & $0.833 * *$ & 0.453 & $0.713^{* *}$ \\
\hline TVC & & & & & & & 1.000 & $-0.811^{* *}$ & $-0.924 * *$ & $-0.755^{* *}$ & $-0.904 * *$ \\
\hline DPPH & & & & & & & & 1.000 & $0.728^{* *}$ & $0.960^{* *}$ & $0.830^{* *}$ \\
\hline App & & & & & & & & & 1.000 & $0.728^{* *}$ & $0.960 * *$ \\
\hline Odor & & & & & & & & & & 1.000 & $0.871^{* *}$ \\
\hline Overall & & & & & & & & & & & $0.736^{* *}$ \\
\hline
\end{tabular}

${ }^{1)}$ weight=weight loss, $\mathrm{BI}=$ browning index, $\mathrm{TP}=$ total phenolic contents, $\mathrm{TVC}=$ total aerobic bacteria, $\mathrm{DPPH}=\mathrm{DPPH}$ radical scavenging ability, $\mathrm{APP}=$ appearance, overall $=$ overall acceptability

2)* $p<0.05, * * p<0.01$ 
게 나타났다. 전반기호도를 기준으로 저장 5일경까지 상업적 품 질을 유지하고 있었다.

Keywords 산소투과도·양상추·Fresh-cut·Modified atmosphere packaging · OPP 필름

\section{References}

Ahvenainen R (1996) New approaches in improving the shelf life of minimally processed fruit and vegetables. Trends in Food Sci Technol 7: 179-187

Barmore CR (1987) Packing technology for fresh and minimally processed fruit and vegetables. J Food Qual 10: 207-217

Boo HO, BG Heo, S Gorinstein, SU Chon (2011) Positive effects of temperature and growth conditions on enzymatic and antioxidant status in lettuce plants. Plant Sci 181: 479-484

Brand-Williams W, Cuvelier ME, Berset C (1995) Use of free radical method to evaluate antioxidant activity. LWT Food Sci Technol 28: 25-30

Brecht JK (1995) Physiology of lightly processed fruits and vegetables. Hort Sci 30: 18-22

Chun OK, Kim DO, Smith N, Schroeder D, Han JT, Lee CY (2005) Daily consumption of phenolics and total antioxidant capacity from fruit and vegetables in the American diet. J Sci Food Agric 85: 1715-1724

Cliffe-Byrnes V, Mc Laughlin CP, O'Beirne D (2003) The effects of packaging film and storage temperature on the quality of a dry coleslaw mix packaged in a modified atmosphere. Int J Food Sci Technol 38: 187-199

Dixon RA, Paiva NL (1995) Stress-induced phenylpropanoid metabolism. The Plant Cell 7: 1085-1097

Fonseca SC, Oliveira FA, Brecht JK (2002) Modeling respiration rate of fresh fruits and vegetables for modified atmosphere packages: a review. J Food Eng 52: 99-119

Hwang TY, Moon KD (2005) Technical trend and prospect of minimal processing fruits and vegetables Industry. Food Sci Ind 38: 120-130

Hwang TY (2013) Quality characteristics of soybean sprouts packaged with different packaging materials during their storage. Korean J Food Preserv 20: $602-607$

Jung JY, Shin SH, Choi JH, Jeong MC (2008) Browning and quality changes of fresh-cut iceberg lettuce by gas flushing packagings. Korean J Sci Technol 26: 406-412

Kays SJ, Paull RE (2004) Postharvest Biology. Exon Press, Athenus, GA,
USA. pp 568

Kang S, Kim M, Choi U (2007) Shelf-life extension of fresh-cut iceberg lettuce (Lactuca sativa L) by different antimicrobial films. J Microbiol Biotechnol 17: 1284-1290

KFDA (2007) Notification No. 2007-63, Korea food and drug administration, Seoul, pp 29-31

Kim JG, Luo Y, Tao Y, Saftner RA, Gross KC (2005) Effect of initial oxygen concentration and film oxygen transmission rate on the quality of freshcut romaine lettuce. J Sci Food Agric 85: 1622-1630

Labuza TP, Brene WM (1989) Applications of active packaging for improvement of shelf-life and nutritional quality of fresh and extended shelf life foods. J Food Process Preserv 13: 1-69

Llorach R, Martinez-Sanchez A, Tomas-Barberan FA, Gil MI, Ferreres F (2008) Characterisation of polyphenols and antioxidant properties of five lettuce varieties and escarole. Food Chem 108: 1028-1038

Martýnez JA, F Artes (1999) Effect of packaging treatments and vacuumcooling on quality of winter harvested iceberg lettuce. Food Res Int 32: 621-627

Panisello PJ, Quantick PC (1998) Application of food MicroModel predictive software in the development of Hazard Analysis Critical Control (HACCP) systems. Food Microbiol 15: 425-439

Pereira GDM, Kothe CI, Machado CC, Lopes SM, Flores SH, Rios ADO (2014) Effect of modified atmosphere applied to minimally processed radicchio (Cichorium intybus L.) submitted to different sanitizing treatments. Food Sci Technol (Campinas) 34: 513-521

Rico D, Martýn-Diana AB, Barat JM, Barry-Ryan C (2007) Extending and measuring the quality of fresh-cut fruit and vegetables: a review. Trends in Food Sci Technol 18: 373-386

Sandhya (2010) Modified atmosphere packaging of fresh produce: current status and future needs. LWT Food Sci Technol 43: 381-392

Serea C, Barna O, Manley M, Kidd M (2014) Effect of storage temperature on the ascorbic acid content, total phenolic content and antioxidant activity in Lettuce (Lactuca Sativa L.). J Anim Plant Sci 24: 1173-1177

Singleton VL, Rossi JA (1965) Colorimetry of total phenolics with phosphomolybdic-phosphotungstic acid reagents. American J Enol Vitic 16: $144-158$

Smyth AB, J Song, AC Cameron (1988) Modified atmosphere packaged cut iceberg lettuce: Effect of temperature and $\mathrm{O}_{2}$ partial pressure on respiration and quality. J Agric Food Chem 46: 4556-4562

Tomas-Barberan FA, Loaiza-Velarde J, Bonfanti A, Saltveit ME (1997) Early wound- and ethylene-induced changes in phenylpropanoid metabolism in harvested lettuce. J Am Soc Hortic Sci 122 (3): 399-404

Zagory D, Kader AA (1988) Modified atmosphere packaging of fresh produce. Food Technol 42: 70-77 